\section{Research \\ isn't the \\ only route}

\section{Anonymous}

(As told to Judy Robertson.)
This recipe is about the experiences of one of our colleagues (let's call her Juliet) who works in academic development, supporting all disciplines throughout the university.

The recipe starts with a pivotal moment in Juliet's life when she decided to change her career track from research in molecular biology to a teaching and learning support role within the University. Her decision was made for positive reasons and she is now thriving personally and professionally. This story highlights the important point that talented and well-qualified women have agency in their own careers and that therefore the onus is on universities to make the working environment attractive enough to entice them to work there.

We know from a recent study of attitudes to professional advancement that women tend to have more life goals, and a wider spectrum of goal types than men (Gino et al., 2015). The female participants in that study felt equally capable of achieving professional advancement and assuming powerful roles - it's just that they found this less desirable. They had other things to do with their lives. The STEM (science, technology, engineering and mathematics) leaky pipeline is a problem for universities: year on year they are losing much of their talent pool. It isn't necessarily a problem for the women themselves.

When I was writing up my PhD at home, I spent hours at the computer, with my daughter pestering me so much that I wondered: "Why is she acting so needy?" and then I realised. She had been missing me.

During all that time when I was doing my research - working early, working late, working weekends - she was being ignored. Due to the nature of my research in molecular biology, experiments are very intensive. If you want a 24-hour growth curve, you need to get yourself a camp bed in the lab and wake yourself up every 30 minutes. While I was looking after my cells, my husband was looking after my daughter. In a way, she had done both degrees with me.

Now I was pregnant again and I suddenly thought I couldn't do this for another child. I asked myself whether I would be able to regulate my working hours to $9-5$, and my answer was "no", not even if I had the self-awareness to try. I had only ever known two part-time researchers in my field: it wasn't the norm. You wouldn't be able to get the results doing part-time. I also realised I wouldn't be able to control my need/desire to get the results. I had seen a lot of people in the lab become obsessed by it. They were so interested in finding out, and refining their ideas that they forgot everything else as I had done.

What could I do? I had to find another job which I would love too. I had some experience of teaching in the department. I enjoyed this, and was progressing fast, getting roles which other PhD students didn't get. 


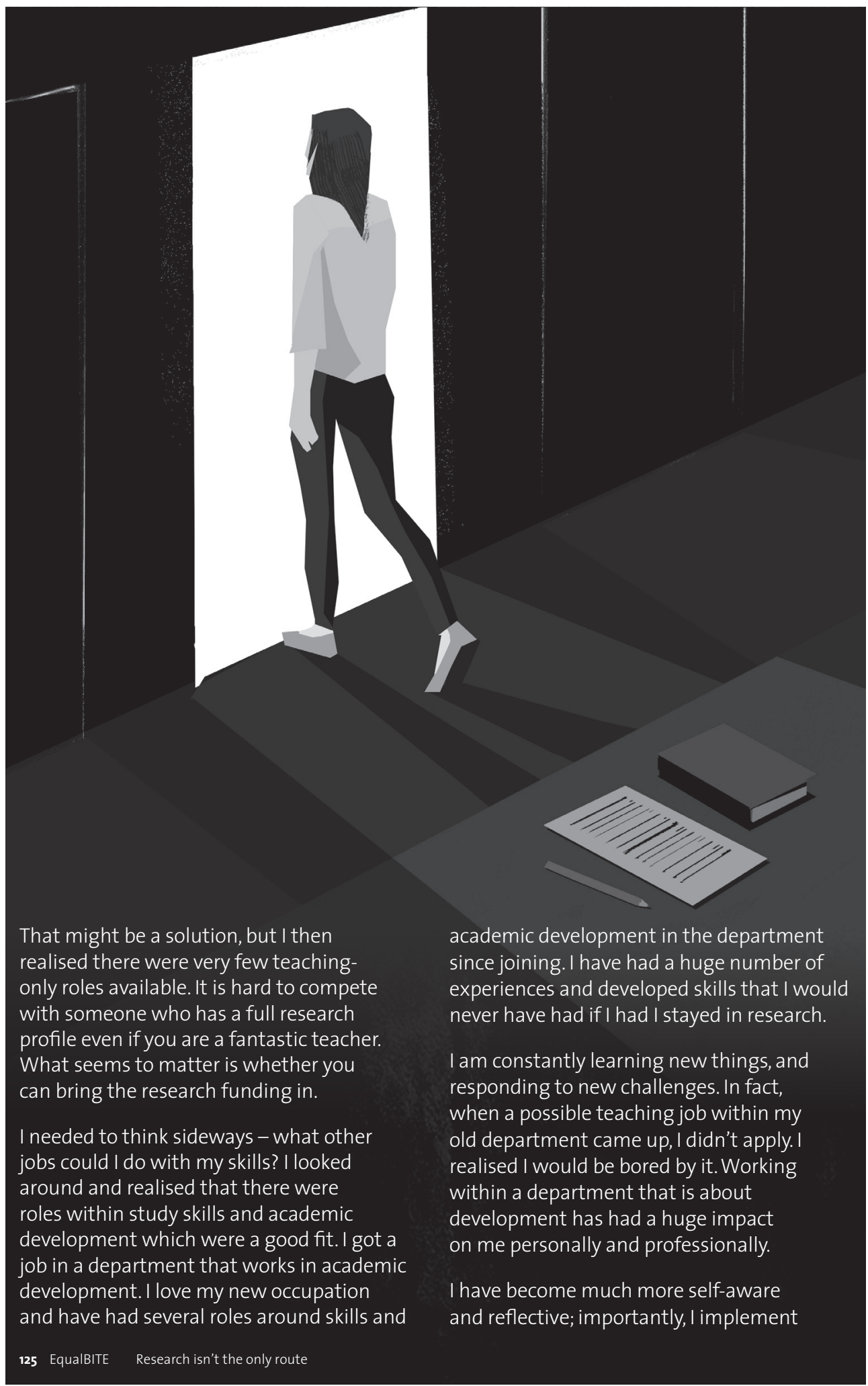


change based on reflection, so I find myself constantly developing both in work and at home. Hopefully, the benefits are not just for me, but have knock-on effects for those around me, family, friends and colleagues.

\section{Ingredients}

- Honesty.

- Self-awareness.

- An open mind.

\section{Method}

\section{Acknowledge when there is a} problem. Now I am more reflective and take stock of life. I try to have an ongoing awareness of balancing all aspects of my life. When I was doing my PhD, I didn't think: "Does this fit with me and my family?" It is useful to reflect from time to time, and to identify when you are feeling unhappy with your situation.

2. Consider the impact your choices have on those around you. Focusing purely on work is to the detriment of everything else. Taking time to move your focus away and notice "life" happening around you can enhance your life or at least let you make a start at it - and life is for living!

3. Consider what your wider skills are and look further than what the seemingly obvious career path is. Maybe your “dream job" isn't really so dreamy after all. Your PhD has given you a valuable set of skills: I know my PhD has enabled me to quickly pick up an issue, analyse it and decide what to do. Look carefully at job ads and think about how they relate to your research experience. For example, your experience in overseeing and ordering lab equipment is an example of budget management. Attend a careers service course on career management to help you consider what you want in your next job-don't be blinkered. The careers service also holds records of graduate destinations which can give you new ideas of what you could do. Alumni networks can also be helpful.

\section{Consider: are you suffering from martyr} syndrome? Academics put up with too much. It is sometimes a badge of honour to work too much and it can give you a chip on your shoulder. Is the work really necessary? Could you be suffering from imposter syndrome where you feel you always have to work harder so you don't get "found out"? Imposter syndrome, which refers to the usually unfounded anxiety that you are an incompetent fraud, is not uncommon among highly capable academics, particularly women (Hutchins \& Rainbolt, 2016). See also: Dealing with imposter syndrome. 


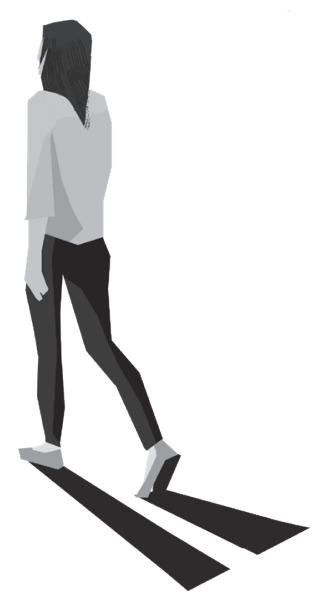

5. For principal investigators: don't imply students who follow other careers have failed. When I decided to give up research, I wondered how to tell my principal investigator. He loved science too. He seemed distraught if his students didn't want to do research. It would be helpful if supervisors could instead encourage their students to consider a range of careers from the outset and help them to build their skills accordingly, for example by valuing inquisitiveness and skills such as logical analysis of situations, and the development of processes. If everyone could do that, we'd be in Star Trek.

6. For universities: consider different funding models. To encourage more people to stay in academia as researchers, change the funding model. Departments could have a fund which every researcher is entitled to, as has been piloted in some universities. This would take the pressure off getting results and enable longer term research. It's not just that women leave academia. Talented researchers, men and women, move to industry where they have open-ended contracts, $9-5$ jobs, good equipment and funding, more staff and no worries that the lab will collapse without the next grant.

Since Juliet received her PhD, various schools at Edinburgh

University have been working on trying to improve the career routes for new researchers to make working in academia a more attractive proposition. For example, the Roslin Institute has invested in Career Track fellowships which fund a research assistant, budget and one internal and one external mentor. This is intended to support an academic to get started, and reduce the burden of lab work so that he or she can have more flexibility in how they spend their time. 